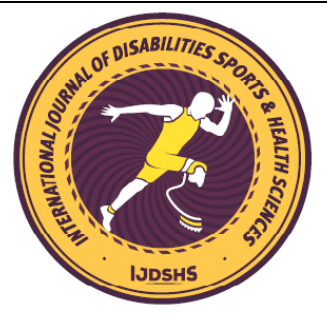

\title{
Burnout Levels of Teachers Working In Special Education
}

\author{
Burcu KAYA $^{1 \text { iD }}$ and Muharrem KÖKLÜ*2 \\ ${ }^{1}$ Asya Special Education and Rehabilitation Center, İstanbul Turkey. \\ ${ }^{*}$ İstanbul Okan University. Faculty of Education, Department of Education Sciences, Istanbul, Turkey \\ *Corresponding author: koklu8@hotmail.com
}

\begin{abstract}
Special education as a type of education involving the education of children whose development is slow compared to their peers and the ability to adapt to society, includes challenging processes for the child's family as well as its teachers. Determining the burnout levels of teachers working in the field of special education has been identified as the main goal of this research. Explanation of physical exhaustion, emotional exhaustion, mental exhaustion of teachers, determination of whether the teacher's views differ according to the domographic characteristics of the teachers are included in the scope of the subgoals. The Maslach Burnout scale was used to collect data in this study, which is in the general screening model. The scale was applied to all special education teachers (142 teachers) working in the field of special education in schools in Eyüpsultan District of Istanbul province. 137 scales have returned. According to the results obtained, working in the field of special education, teachers generally have "some" level $(X=2,63 \pm$ of 0.38$)$; in the dimension of emotional exhaustion: "sometimes" level $(X=2,84 \pm 0,49)$; mental exhaustion in the size of the "sometimes" level $(X=2,68 \pm 0,39)$; physical exhaustion in the size of "very rare" level $(\mathrm{x}=$ is $2.38 \pm 0,64)$ were found to have employee burnout. It was found that the burnout levels of teachers differed according to age, gender, branch, type of institution studied, and duration of work in the field of special education.
\end{abstract}

Keywords

Special Training, Burnout, Teachers' Burnout

\section{INTRODUCTION}

Along with the developments in the field of education, the development of special education has gained positive momentum. As a result of the developments related to special education, special education has become a discipline in its own right and trainings have been given in the field of special education at the academic level. This point achieved by special education is one of the main factors in selecting such a subject of study.

Special education is a challenging process. Education of children who do not show Normal development will not occur only with education provided in school. For this reason, teachers in special education should carry out their work in a coordinated manner with the family. The existence of such a requirement increases the level of attrition of teachers working in the field of special education, as well as increases the level of difficulties encountered. In addition, in this process, the family's experiences with a child who needs special education inevitably affect teachers. All these are factors in preparing a study on this issue.

Stress is expressed as the disease of the modern age. The relationship between stress and this study is that people's work under intense stress increases the likelihood of burnout syndrome. The idea that teachers working in the field of special 
education will experience this situation more intensively brings about the effects of stress as well as burnout.

Burnout syndrome is described as a psychological problem that occurs with stress in the working environment and the continuation of similar conditions (Sağlam Arı and Çına Bal, 2008: 133). This aspect of burnout, in addition to its intense presence in working life, leads to its being in a position that affects employees emotionally, behaviorally and mentally. In the study, it is designed to focus on the reflections of burnout in working life in detail.

One of the biggest problems faced by today's employees is burnout. Along with the continuity of difficulties encountered in organizational processes, employees are more likely to develop burnout syndrome, and therefore there is an increase in the number of burnout research. In the research to be conducted, examples of the emergence and development of burnout will be given and the scope of the concept will be revealed. People's work environment, relationships with colleagues, workload, fair approach, rewards and personal values cause burnout and reveal the symptoms of burnout (Budak and Sürgevil, 2005: 97). Determining the factors that cause burnout of teachers working in the field of special education is one of the issues that cause the problem situation.

Burnout has negative effects on both individual and organizational levels in working life (Ardıç and Polatçı, 2008: 69). The negative effects of burnout, the fact that it is in a position to directly affect performance from the point of view of teachers working in an important area such as special education, are a structure that should be taken into account within the scope of the problem situation of the study. One of the important issues about burnout is the fight against burnout. With the belief that the most valuable asset in organizations is human resources, emphasis has begun to be placed on combating issues with negative effects such as burnout. Issues that should be considered at the individual and organizational level when combating burnout have been identified as one of the topics that the study will investigate.

In this study, which will be prepared with the aim of explaining the burnout levels of teachers working in the field of special education, the reflection of the difficulties encountered in special education on the lives of teachers was taken as the starting point. In the assessment, progress will be made by taking into account the impact of humanitarian challenges that teachers working in the field of special education face in addition to the challenges they face professionally. In this way, the burnout of teachers working in the field of special education will be demonstrated in a multifaceted form.

Teachers working in the field of special education are affected by what they face, and this is a decisive position in the emergence of a problem situation in the study. Reflection of teachers ' experiences in their own lives in processes related to special education constitutes a problem situation. The fact that teachers in the field of special education are affected by the situation in which special education students and their families are located creates a situation of problems.

The fact that the possible challenges are greater than in other branches is one of the important details in the scope of special education. Issues with negative content such as stress, burnout and anxiety are more common in k special education services (Bayrakdar, Vural Batk and Barut, 2015: 135). This, in turn, is a structure that should be considered for the scope and effects of special education. The scope of special education in terms of education-related processes is shown in Table 1 below (MFSPR,Turkey 2018).

According to the data in Figure 1.1, information must be activated first within the scope of special education. In the second stage, steps related to content editing are taken. Teaching terms and concepts are among the factors that should be known within the scope of special education. The fact that it contains information about how to follow a path in special education is a factor that increases the importance of the data contained in the above figure.

One of the issues that should be addressed within the scope of special education is the issue of inadequacy. 
Table 1. Scope of Special Education

\begin{tabular}{|c|c|c|}
\hline $\begin{array}{l}\text { Activate Previous } \\
\text { Information }\end{array}$ & Edit Content & $\begin{array}{l}\text { Learning terms and } \\
\text { concepts }\end{array}$ \\
\hline $\begin{array}{l}\text { Associate with previous } \\
\text { information }\end{array}$ & $\begin{array}{l}\text { Defining the main topics, } \\
\text { activities. Presenting content } \\
\text { outlines, providing } \\
\text { preliminary information, etc. }\end{array}$ & $\begin{array}{c}\text { Examples, synonyms and } \\
\text { diversification of } \\
\text { definitions }\end{array}$ \\
\hline $\begin{array}{l}\text { Consideration of previous } \\
\text { information }\end{array}$ & $\begin{array}{c}\text { Sequence of events, } \\
\text { comparison, cause and effect } \\
\text { relations }\end{array}$ & $\begin{array}{l}\text { Distinguishing positive } \\
\text { or negative examples }\end{array}$ \\
\hline $\begin{array}{c}\text { Deciding which } \\
\text { information should be } \\
\text { given priority }\end{array}$ & Creating a working guide & \\
\hline & $\begin{array}{c}\text { Using graphic and visual } \\
\text { editing }\end{array}$ & \\
\hline
\end{tabular}

These deficiencies that shape special types of education are listed as follows (Karasu and Mutlu, 2014: 48)

\begin{tabular}{ll}
\hline i. Attention deficit and hyperactivity & vii. Specific learning disabilities \\
ii. Language and speech & viii. Autism \\
iii.Emotional and behavioral disorders & ix. Cerebral palsy \\
iv. Seeing & x. Continuum disease \\
v. Hearing & xi. Mental disabilities is shaped \\
vi. Orthopedics & \\
\hline
\end{tabular}

Deficiencies in the mentioned subjects are effective in clarifying the scope of special education. Each of these deficiencies is important separately, as they have a different effect on the final version of the scope of special education. Institutions operating in the field of special education are one of the determining factors related to the scope and effects of special education. As a newly developing area, the number of private educational institutions is not very large (Gündüz and Akın, 2015: 87). Private educational institutions, whose prevalence is not high, are an obstacle to the number of people reached by the effects of private education at the desired level. For this reason, the dissemination of special education institutions has to be one of the priority goals related to special education.
In Figure 1 (Tümeğ, 2014), the place and importance of teachers working in the field of special education in the special education process are discussed in two periods, before and after teaching. It includes the process of providing material control, attracting the attention of the student with special educational needs, telling what the topic to study works, determining the rules and rewards before teaching. In the teaching process, teachers working in the field of special education talk about the content in the form of teaching with simultaneous tips, giving correct reactions, not reacting according to their place. In terms of showing that teachers working in the field of special education continue to exist in different ways in special education processes according to the stage of education, these considerations must be taken into account. 


\section{Educating A Student With Disabilities As A Teacher}

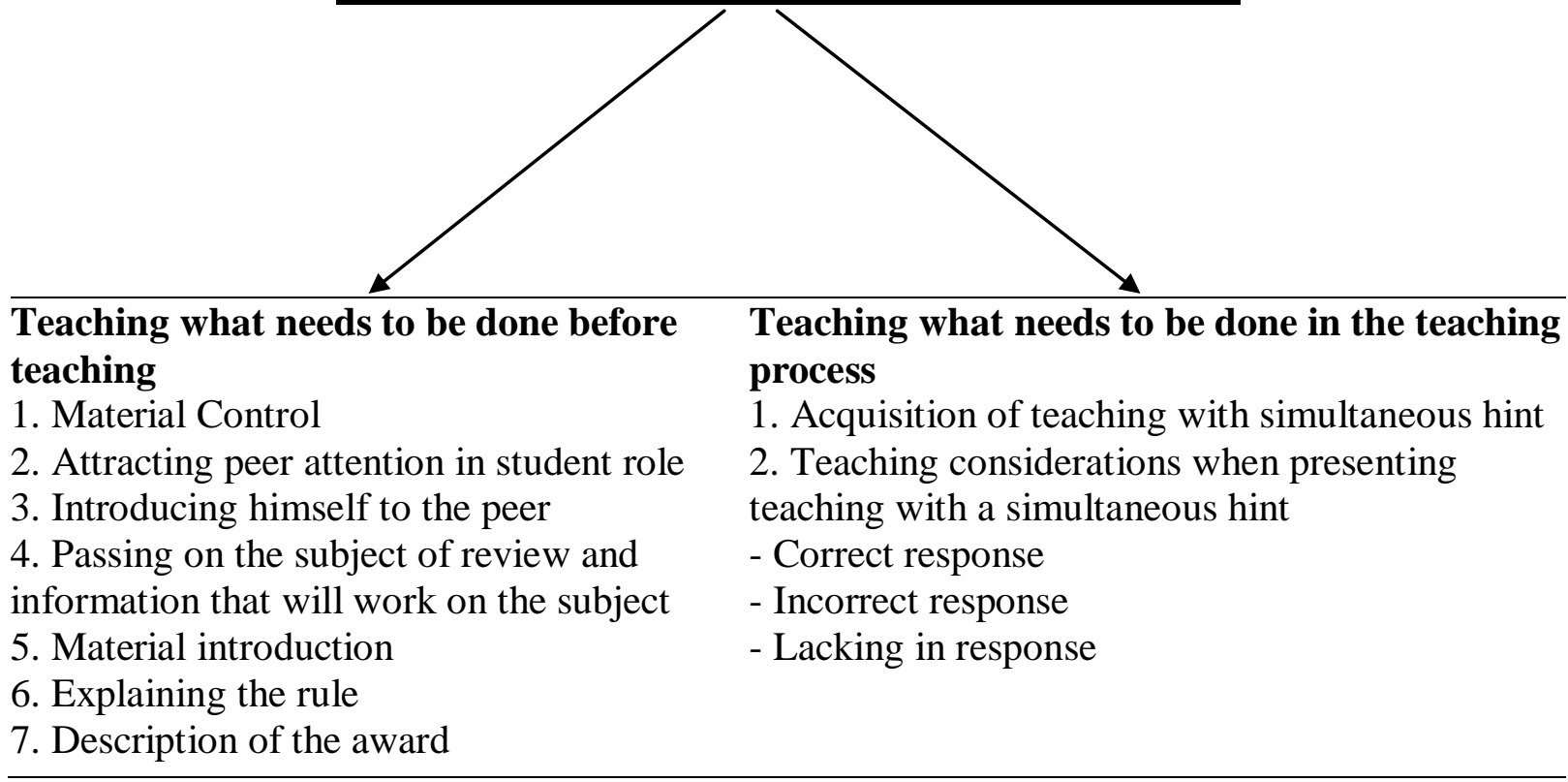

\section{Figure 1. Main Roles Of Teachers In Special Education}

"In our country, teachers working in special education institutions are considered special education teachers regardless of their educational status and branches" (Başaran, 2001: 41), while special education faculties should include graduates of the special education department, the program for teaching hearing, vision and mental disabilities. It is understood through these statements that there may be differences from country to country regarding the place and importance of teachers working in the field of special education in special education. However, it is seen that teachers working in the field of special education can work in many different areas in special education services.

Teachers working in the field of special education have to contribute to the development of students who are experiencing inadequacy. The difficulty of dealing with children with special educational needs stands out as a factor that complicates the task of teachers working in the field of special education (Başaran, 2001: 41). First, it is necessary to be aware that these teachers perform their duties with many difficulties when examining the duties of teachers working in the field of special education.

Competence in classroom management is one of the duties of teachers working in the field of special education. At this point, it is expressed that there is a need for support, especially for teachers of inclusion education (Akalin, 2015: 215). Although inclusion education teachers stand out a little more, this requirement applies to all teachers working in the field of special education. In order to increase the quality of special education, the competence of teachers working in the field of special education has a very important place in this regard.

Patience and dedication are among the duties of teachers working in the field of special education. The difficulties encountered in the process of providing education to children with special education needs significantly affect teachers working in the field of special education, but point out that they should be treated patiently and devotion should be shown throughout the process (Şahin and Şahin, 2012: 277).

\section{Purpose of research}

"To present the views of teachers working in the field of special education about the level of burnout; to determine whether the views of teachers differ according to the variables of gender, age, branch, type of institution, year studied in special education."arranged in the form. In order to achieve this general goal, answers to the following questions have been sought.

1. What is the level of burnout of teachers working in the field of special education in the lower dimensions and in general?

2. Do the burnout situations of teachers working in the field of special education differ significantly by lower dimensions and gender in general? 
3. Do the burnout situations of teachers working in the field of special education differ significantly depending on the lower dimensions and age in general?

4. Do the burnout situations of teachers working in the field of special education differ significantly depending on the lower dimensions and the branch in general?

5. Do the burnout situations of teachers working in the field of special education differ significantly depending on the lower dimensions and the type of institution they are in charge of in general?

6 . Do the burnout situations of teachers working in the field of special education differ significantly depending on the lower dimensions and the year of work in the field of special education in general?

\section{Importance of Research}

People's changing lifestyles and the increasing structure of stress in human life have led to burnout being a more common structure. At the beginning of the elements that make up the importance of this research is the increase in the frequency of people experiencing burnout syndrome. From the point of view of teachers working in the field of special education, the interaction of the difficulty of educating special education students with burnout creates the scientific importance of the selected subject. The importance of the research is that teachers working in the field of special education will provide explanations on how to combat burnout. The focus on the level of difficulties and burnout faced by teachers working in the field of special education compared to other teachers is the distinctive aspect and importance of the research.

\section{MATERIALS AND METHODS}

This research is patterned on the general screening model for the study of burnout levels of teachers working in special education.

\section{Participant}

Teachers working in the field of special education working in special education centers and schools in Eyüpsultan District of Istanbul Province were included in the study. No sample was created in this study. The entire universe (142 teachers) had scales distributed, and 137 scales returned. Thus, the findings were obtained from 137 scale data returned.

\section{Data Collection Tool}

Scale was used as a means of data collection. The scale consisted of two parts. The first section to find some information about teachers ' age, gender, major, type of institution, and years of working in the field of special education for the variable "personal information form", the second part is a Likert-type 5-choice questions 22 and Jackson Health literature (1981) was developed by and Capri (2006) adapted to Turkish by, 3 subdimensions of Burnout scale has been involved in the health literature. Plot 5, 8, 12, 14, 17, 21. questions emotional exhaustion, $3,6,9,11,15,18$, 19. questions mental exhaustion, $1,4,7,10,13$, 16, 20. the questions are about physical exhaustion.

\section{Statistical Analysis}

In the study, the arithmetic mean(X) was used to determine the level of burnout. "Never" for 1.00-180, "very rare" for 1.81-2.60, "sometimes" for 2.61-3.40, "most of the time" for 3.41-4.20, "always" for 4.21-5.00 were used in the interpretation of the arithmetic mean.

Compliance with the normal distribution was tested using the Shapiro-Wilk-w test to determine whether the variables fit the normal distribution. Normal distribution results are shown in Table 2.

Table 2. Normality Test

\begin{tabular}{lccc}
\hline & \multicolumn{3}{c}{ Shapiro-Wilk } \\
\cline { 2 - 4 } & Statistic & df & Sig. \\
\hline Emotional exhaustion & 0,977 & 137 & 0,019 \\
\hline Mental exhaustion & 0,979 & 137 & 0,033 \\
\hline Physical exhaustion & 0,981 & 137 & 0,049 \\
\hline Burnout (General) & 0,989 & 137 & 0,351 \\
\hline
\end{tabular}


As can be seen in Table 2, it was found that the group did not exhibit normal distribution according to the variables of emotional exhaustion, mental exhaustion and physical exhaustion. Since the group did not show normal distribution, the Mann Whitney -U test was used to compare two groups, and the Kruskal Wallis test was used to compare three and more groups. The Mann Whitney U test was performed to determine which groups had a significant difference in the Kruskal test.

It has been found that the group exhibits a normal distribution in the overall depletion size. Since the distribution is normal, the t-test for variables with two groups was used to analyze one-way variance (ANOVA) for variables with more than two groups. In order to determine the groups that cause the difference as a result of ANOVA, the homogeneity of the variances was first looked at using the Levene test. If the variances are homogeneous, the Schefe test was used, and if not, the Tamhane test was used.

\section{RESULTS}

The first teachers in the study of emotional, mental, physical dimensions and overall burnout levels of teachers in the continuation of tukenmislik of opinions about gender, age, branch, task carried institution, according to the variables of years of working in the field of special education was investigated and results showed significant differences are indicated by using tables.

\section{Teachers ' Burnout Levels}

Arithmetic ratios were calculated to determine the lower dimensions of teachers and their level of burnout in general. The findings are included in Table 3.

Table 3. Number, arithmetic mean and standard deviation values of Teachers ' views on Burnout

\begin{tabular}{|c|c|c|c|c|}
\hline Bottom Size & Expression (article) & $\mathbf{n}$ & $\overline{\bar{\chi}}$ & SS \\
\hline \multirow{9}{*}{ 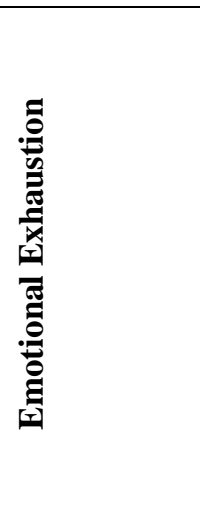 } & 2 , return to work I feel spiritually exhausted. & 137 & 2,32 & 0,87 \\
\hline & $\begin{array}{l}5 \text {, I realize that I treat some of the people I meet as if they are not } \\
\text { people. }\end{array}$ & 137 & 1,51 & 0,78 \\
\hline & 8, I feel exhausted from the work I've done. & 137 & 2,34 & 1,2 \\
\hline & 12, I'm able to do a lot of things. & 137 & 3,72 & 1,04 \\
\hline & 14, I feel like I'm working too hard at my job. & 137 & 2,81 & 1,31 \\
\hline & $\begin{array}{l}\text { 17, I create a comfortable atmosphere between me and the people I } \\
\text { meet for my job. }\end{array}$ & 137 & 3,28 & 1,01 \\
\hline & 21, I approach emotional problems in my work with coolness. & 137 & 3,41 & 1,03 \\
\hline & $\begin{array}{l}22, \text { I feel that some of the people I encounter in my work are acting as } \\
\text { if I created some of their problems. }\end{array}$ & 137 & 1,88 & 0,89 \\
\hline & Bottom Size & 137 & 2,84 & $\mathbf{0 , 4 9}$ \\
\hline \multirow{8}{*}{ 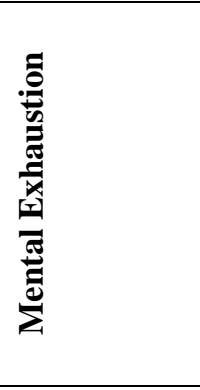 } & $\begin{array}{l}\text { 3, when I wake up in the morning, I feel like I can't handle this job for } \\
\text { another day. }\end{array}$ & 137 & 1,92 & 1,05 \\
\hline & 6 , dealing with people all day is really exhausting for me. & 137 & 2,45 & 1,01 \\
\hline & 9, I believe that through the work I do, I contribute to people's lives. & 137 & 3,9 & 1,09 \\
\hline & 11, I'm afraid this job will make me harder and harder. & 137 & 2,05 & 1,12 \\
\hline & 15 , I don't care what happens to the people I meet because of my job. & 137 & 1,43 & 0,82 \\
\hline & 18, I feel alive after working closely with people. & 137 & 3,45 & 0,94 \\
\hline & 19, I have had many notable successes in this business. & 137 & 3,56 & 0,97 \\
\hline & Bottom Size & 137 & 2,68 & $\mathbf{0 , 3 9}$ \\
\hline \multirow{8}{*}{ 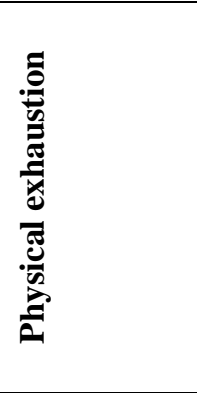 } & 1, I feel like I'm cooling off from my job. & 137 & 2,08 & 0,92 \\
\hline & 4, because of my job, I understand how the people I meet feel. & 137 & 3,45 & 1,04 \\
\hline & $\begin{array}{l}7 \text {, I find the most appropriate solutions to the problems of the people I } \\
\text { encounter in my work. }\end{array}$ & 137 & 3,64 & 0,88 \\
\hline & 10, I've been hard on people since I worked in this business. & 137 & 1,96 & 0,92 \\
\hline & $13, \mathrm{I}$ feel like my work is holding me back. & 137 & 2,4 & 1,3 \\
\hline & 16, working directly with people puts a lot of stress on me. & 137 & 2,47 & 1,01 \\
\hline & 20, I feel like I'm at the end of the road. & 137 & 1,75 & 1,07 \\
\hline & Bottom Size & 137 & 2,38 & 0,64 \\
\hline \multicolumn{2}{|c|}{ Burnout (General) } & 137 & 2,63 & $\mathbf{0 , 3 8}$ \\
\hline
\end{tabular}


Looking at the arithmetic averages in Table 3 , teachers ' emotional exhaustion states were found to be greater than their mental and physical states. It turned out that the level of burnout was at the level of "sometimes" in the emotional and mental dimensions; at the level of "very rare" in the physical dimension; at the level of "sometimes" in general.

With the lowest arithmetic average of 1.51 in the sub-dimension of emotional exhaustion, " 5 , I realize that I treat some of the people I encounter as if they are not people. "At the level of" None "in his statement and with the highest arithmetic average of 3.72 " 12, I am able to do a lot of things. It was found to be at the level of "most of the time" and at the level of "sometimes" with an average of $2.84 \pm 0.49$ in the total score of the lower dimension.

With the lowest arithmetic average of 1.43 in the lower dimension of mental exhaustion, " 15 , I don't care what happens to the people I meet because of my job. "At the level of" ever "in his statement and with the highest arithmetic average of 3.90, " 9, I believe I contribute to people's lives thanks to the work I do."It is included in the statement and is at the level of" most of the time "and the overall average score of the lower dimension is at the level of" sometimes " with an average of $2.68 \pm 0.39$.

With the lowest arithmetic average of 1.75 in the lower dimension of physical exhaustion, "20, I feel like I've come to the end of the road." In the expression "Never," and at the highest level with the arithmetic average 3,64 " 7 , find the most appropriate solution to the problems of the people I encountered in my job I will," the statement is located in the "often" and at the level of subdimensions in total average score is $2.38 \pm 0,64$ average "very rare" - size and level of burnout (in general) 2,63 \pm average of 0.38 "sometimes" level.

\section{Burnout Status Of Teachers By Gender}

The Mann Whitney U test was performed to determine whether emotional, physical, and mental exhaustion states differ significantly by gender. The findings are included in Table 4.

Table 4. Results Of The Mann Whitney U Test By Gender Of Emotional, Mental And Physical Exhaustion Scores

\begin{tabular}{|c|c|c|c|c|c|c|}
\hline & & $\bar{n}$ & $\begin{array}{l}\text { Rank } \\
\text { Average }\end{array}$ & $\begin{array}{l}\text { Sequence } \\
\text { Sum }\end{array}$ & M.W.-U & $\overline{\mathbf{p}}$ \\
\hline \multirow{2}{*}{$\begin{array}{l}\text { Emotional } \\
\text { exhaustion }\end{array}$} & Woman & 111 & 64,14 & 7120,00 & \multirow[t]{2}{*}{904,000} & \multirow[t]{2}{*}{$0,003^{*}$} \\
\hline & Man & 26 & 89,73 & 2333,00 & & \\
\hline \multirow[t]{2}{*}{ Mental exhaustion } & Women & 111 & 65,41 & 7260,00 & \multirow[t]{2}{*}{1044,000} & \multirow[t]{2}{*}{$0,027 *$} \\
\hline & Man & 26 & 84,35 & 2193,00 & & \\
\hline \multirow[t]{2}{*}{ Physical exhaustion } & Women & 111 & 64,71 & 7183,00 & \multirow[t]{2}{*}{977,000} & \multirow[t]{2}{*}{$0,009 *$} \\
\hline & Man & 26 & 87,31 & 2270,00 & & \\
\hline
\end{tabular}

As can be seen in Table 4, The opinions of male and female teachers differ according to the gender variable in all three dimensions, emotional, mental, and physical states of exhaustion. In all three dimensions, it appears that male teachers are more likely to be in burnout than female teachers.

Table 5. t-Test results by gender of overall burnout scores

\begin{tabular}{llccccc}
\hline \hline & & $\mathbf{n}$ & $\overline{\mathbf{x}}$ & $\mathbf{S S}$ & $\mathbf{t}$ & $\mathbf{p}$ \\
\hline \multirow{2}{*}{ Burnout (General) } & Women & 111 & 2,58 & 0,37 & $-3,217$ & $0,002 *$ \\
\cline { 2 - 6 } & Man & 26 & 2,84 & 0,39 & & \\
\hline
\end{tabular}

Looking at the arithmetic averages in Table 5, male teachers show more burnout than female teachers in general. Thus, both in general and in
An Independent Group t-test was performed to determine whether general burnout conditions differ significantly by gender. The findings are in Table 5. the three sub-dimensions, male teachers show more burnout than female teachers. 


\section{Burnout Status Of Teachers By Age}

Teachers emotional, physical, mental exhaustion and burnout differ significantly by the age of the event to determine whether the three sub-dimension, Kruskal-Wallis $\mathrm{h}$ test, the general ANOVA was applied to determine whether the differ significantly by age of burnout status. The findings are included in Table 6 and Table 7.

Table 6. Kruskal Wallis Test Results By Age Of Teachers ' Views On Emotional, Mental And Physical Exhaustion

\begin{tabular}{|c|c|c|c|c|c|c|c|}
\hline $\begin{array}{l}\text { Bottom } \\
\text { Size }\end{array}$ & $\begin{array}{l}\text { Age Group } \\
\text { (Year) }\end{array}$ & $\mathbf{n}$ & $\begin{array}{c}\text { Rank } \\
\text { Average }\end{array}$ & Sd & $\chi^{2}$ & $\mathbf{p}$ & Source Of Difference \\
\hline \multirow{6}{*}{ 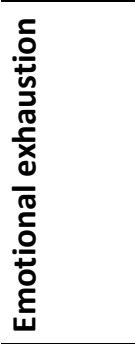 } & $18-23$ & 13 & 37,58 & 4 & \multirow{6}{*}{16,141} & \multirow{6}{*}{$0,003^{*}$} & $24-29>18-23$ \\
\hline & $24-29$ & 46 & 61,14 & & & & $30-36>18-23$ \\
\hline & $30-36$ & 38 & 74,28 & & & & $45-51>18-23$ \\
\hline & $45-51$ & 33 & 82,09 & & & & 52 years and older $>18-23$ \\
\hline & $\begin{array}{l}52 \text { years and } \\
\text { older }\end{array}$ & 7 & 88,64 & & & & $24-29>45-51$ \\
\hline & Total & 137 & & & & & \\
\hline \multirow{6}{*}{ 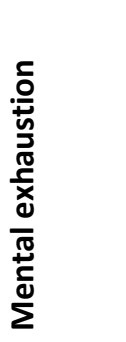 } & $18-23$ & 13 & 42,77 & 4 & \multirow{6}{*}{12,368} & \multirow{6}{*}{$0,015^{*}$} & $30-36>18-23$ \\
\hline & $24-29$ & 46 & 66,10 & & & & $45-51>18-23$ \\
\hline & $30-36$ & 38 & 65,41 & & & & 52 years and older $>18-23$ \\
\hline & $45-51$ & 33 & 84,47 & & & & $24-29>45-51$ \\
\hline & $\begin{array}{l}52 \text { years and } \\
\text { older }\end{array}$ & 7 & 83,36 & & & & $30-36>45-51$ \\
\hline & Total & 137 & & & & & \\
\hline \multirow{7}{*}{ 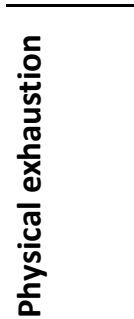 } & $18-23$ & 13 & 29,65 & 4 & \multirow{7}{*}{22,525} & \multirow{7}{*}{$0,000 *$} & $24-29>18-23$ \\
\hline & $24-29$ & 46 & 60,16 & & & & $30-36>18-23$ \\
\hline & $30-36$ & 38 & 77,76 & & & & $45-51>18-23$ \\
\hline & $45-51$ & 33 & 83,03 & & & & 52 years and older $>18-23$ \\
\hline & 52 years and & 7 & 86,43 & & & & $24-29>30-36$ \\
\hline & older & & & & & & $24-29>45-51$ \\
\hline & Total & 137 & & & & & \\
\hline
\end{tabular}

Looking at the "p" values in Table 6, Teacher burnouts in the lower dimensions of emotional, mental, physical exhaustion differ significantly according to the age groups of teachers $(p<.05)$. Looking at the source of the difference in the size of emotional exhaustion, it was found that the emotional exhaustion States of

Looking at the source of the difference in the size of mental exhaustion, it was found that the mental exhaustion States of teachers aged 30-36 years, 45-51 years and 52 years and older were higher than the mental exhaustion States of teachers aged 18-23 years. In addition, it was found that the mental exhaustion States of teachers aged 24-29 years and 30-36 years were higher than the mental exhaustion States of teachers aged 4551 years. teachers aged 24-29 years, 30-36 years, 45-51 years and 52 years and older were higher than the emotional exhaustion States of teachers aged 1823 years. In addition, it was found that the emotional exhaustion States of teachers aged 2429 years were higher than the emotional exhaustion States of teachers aged 45-51 years.

Looking at the source of the difference in the size of physical exhaustion, it was found that teachers aged 24-29 years, 30-36 years, 45-51 years and 52 years and older had higher physical exhaustion conditions than teachers aged 18-23 years. In addition, it was found that teachers 24-29 years of age had higher physical exhaustion than teachers 30-36 years of age and 45-51 years of age. 
Table 7. ANOVA results of teachers ' views on general burnout by age

\begin{tabular}{|c|c|c|c|c|c|c|c|c|c|c|}
\hline \multirow{2}{*}{$\begin{array}{l}\text { Age Group } \\
\text { (Year) }\end{array}$} & \multirow[b]{2}{*}{$\mathbf{n}$} & \multirow{2}{*}{$\bar{\chi}$} & \multirow[b]{2}{*}{ SS } & \multicolumn{6}{|c|}{ ANOVA results } & \multirow{2}{*}{$\begin{array}{c}\text { LSD } \\
\text { Source Of } \\
\text { Difference }\end{array}$} \\
\hline & & & & $\begin{array}{l}\text { Source of } \\
\text { variance }\end{array}$ & $\begin{array}{l}\text { Sum Of } \\
\text { Squares }\end{array}$ & sd & $\begin{array}{l}\text { Squares } \\
\text { Average }\end{array}$ & $\mathbf{F}$ & $\mathbf{p}$ & \\
\hline $18-23$ & 13 & 2,20 &, 34 & Within group & 4,019 & 4 & 1,005 & \multirow[t]{6}{*}{8,265} & 0,000* & \multirow{6}{*}{$\begin{array}{c}24-29>18-23 \\
30-36>18-23 \\
45-51>18-23 \\
52 \text { years and older } \\
>18-23\end{array}$} \\
\hline $24-29$ & 46 & 2,55 &, 28 & Inter groups & 16,050 & 132 & 0,122 & & & \\
\hline $30-36$ & 38 & 2,67 & ,31 & Total & 20,069 & 136 & & & & \\
\hline $45-51$ & 33 & 2,81 &, 45 & & & & & & & \\
\hline $\begin{array}{l}52 \text { and } \\
\text { above }\end{array}$ & 7 & 2,81 &, 43 & & & & & & & \\
\hline Total & 137 & 2,63 & 38 & & & & & & & \\
\hline
\end{tabular}

Looking at the "p" value in Table 7 , it is seen that there is a significant difference between teacher opinions relative to the age variable in relation to the general burnout of teachers. Looking at the source of the difference, it was found that the general burnout conditions of teachers aged 24-29 years, 30-36 years, 45-51 years and 52 years and above were higher than the general burnout conditions of teachers aged 18-23 years.

Thus, both the emotional, mental, physical sub-dimensions and the burnout of teachers in general differ significantly depending on the age variable. It was revealed that the source of the difference was predominantly the 18-23 age group. This age group shows less burnout than other groups with an older age.

\section{Burnout Status Of Teachers By Branch}

In order to determine whether teachers emotional, physical, and mental burnout states differ significantly by branch, the Kruskal Wallis $h$ test in three sub-dimensions and Anova were applied to determine whether general burnout states differ significantly by branch. The findings are included in Table 8 and Table 9.

Table 8. Kruskal Wallis Test Results Of Teachers ' Views On Emotional, Mental And Physical Exhaustion

\begin{tabular}{|c|c|c|c|c|c|c|c|}
\hline $\begin{array}{c}\text { Bottom } \\
\text { Size }\end{array}$ & Branch & $\mathbf{n}$ & $\begin{array}{c}\text { Rank } \\
\text { Average }\end{array}$ & Sd & $\chi^{2}$ & $\mathbf{p}$ & $\begin{array}{l}\text { Source Of } \\
\text { Difference }\end{array}$ \\
\hline \multirow{6}{*}{ 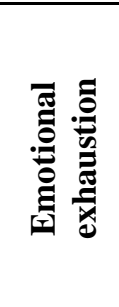 } & Pre-school teaching & 24 & 66,38 & \multirow{6}{*}{4} & \multirow{6}{*}{6,021} & \multirow{6}{*}{0,198} & \\
\hline & Special education teaching & 52 & 67,68 & & & & \\
\hline & Classroom teacher & 20 & 86,55 & & & & \\
\hline & Child Development and Education Teacher & 15 & 55,00 & & & & \\
\hline & Another & 26 & 68,63 & & & & \\
\hline & Total & 137 & & & & & \\
\hline \multirow{6}{*}{ 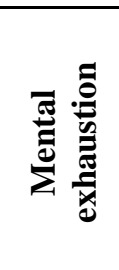 } & Pre-shool teaching & 24 & 61,96 & \multirow{6}{*}{4} & \multirow{6}{*}{4,183} & \multirow{6}{*}{0,382} & \\
\hline & Special Education teaching & 52 & 66,31 & & & & \\
\hline & Classroom teacher & 20 & 83,55 & & & & \\
\hline & Child Development and Education Teacher & 15 & 74,77 & & & & \\
\hline & Another & 26 & 66,37 & & & & \\
\hline & Total & 137 & & & & & \\
\hline \multirow{6}{*}{ 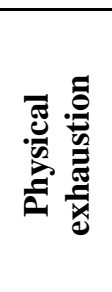 } & Pre-school teaching (1) & 24 & 77,27 & \multirow{6}{*}{4} & \multirow{6}{*}{14,947} & \multirow{6}{*}{$0,005 *$} & \multirow{6}{*}{$\begin{array}{l}1>4 \\
3>2 \\
3>4 \\
3>5\end{array}$} \\
\hline & Special education teaching (2) & 52 & 66,82 & & & & \\
\hline & Classroom teacher (3) & 20 & 93,83 & & & & \\
\hline & Child Development and Education Teacher (4) & 15 & 48,53 & & & & \\
\hline & Another (5) & 26 & 58,44 & & & & \\
\hline & Total & 137 & & & & & \\
\hline
\end{tabular}


Looking at the "p" value in Table 8, teachers ' burnouts differ significantly in the lower dimension of physical exhaustion. Looking at the source of the difference, it was found that the physical attrition status of classroom teachers working in special education is higher than the physical attrition status of teachers working in special education teaching, Child Development and education teacher and other branches. It has also been found that the physical attrition States of preschool teachers are higher than the physical attrition States of Child Development and learning teachers.

Table 9. ANOVA Results of Teachers 'Views on General Burnout by Branch

\begin{tabular}{|c|c|c|c|c|c|c|c|c|c|c|}
\hline \multirow[b]{2}{*}{ Branch } & \multirow[b]{2}{*}{$\mathbf{n}$} & \multirow[b]{2}{*}{$\bar{\chi}$} & \multirow[b]{2}{*}{ SS } & \multicolumn{6}{|c|}{ ANOVA results } & \multirow{2}{*}{$\begin{array}{c}\text { LSD } \\
\text { Source } \\
\text { Of } \\
\text { Differenc } \\
\text { e }\end{array}$} \\
\hline & & & & $\begin{array}{c}\text { Source of } \\
\text { variance }\end{array}$ & $\begin{array}{l}\text { Sum Of } \\
\text { Squares }\end{array}$ & sd & $\begin{array}{l}\text { Squares } \\
\text { Average }\end{array}$ & $\mathbf{F}$ & $\mathbf{p}$ & \\
\hline Pre-school teaching(1) & 24 & 2,64 & 29 & $\begin{array}{l}\text { Within } \\
\text { group }\end{array}$ & 1,949 & 4 & ,487 & \multirow{6}{*}{3,549} & \multirow{6}{*}{$0,009 *$} & \multirow{6}{*}{$\begin{array}{l}3>4 \\
3>5\end{array}$} \\
\hline $\begin{array}{l}\text { Special Education } \\
\text { teaching (2) }\end{array}$ & 52 & 2,60 &, 32 & $\begin{array}{l}\text { Inter } \\
\text { groups }\end{array}$ & 18,120 & 132 & ,137 & & & \\
\hline Classroom teacher (3) & 20 & 2,88 &, 55 & Total & 20,069 & 136 & & & & \\
\hline $\begin{array}{l}\text { Child Development and } \\
\text { Education Teacher (4) }\end{array}$ & 15 & 2,44 & 40 & & & & & & & \\
\hline Another(5) & 26 & 2,58 & ,33 & & & & & & & \\
\hline Total & 137 & 2,63 &, 38 & & & & & & & \\
\hline
\end{tabular}

Looking at the "p" value in Table 9, it seems that the overall burnout levels of teachers differ significantly according to the branch variable. Looking at the source of the difference, it was found that the general burnout conditions of classroom teachers working in the field of special education were higher than the general burnout conditions of Child Development and education teachers and other teachers. Thus, in the physical attrition and general attrition dimensions, the attrition status of classroom teachers working in the field of special education is higher than that of teachers working in special education who are outside themselves.

\section{Burnout Status Of Teachers By Type of Institution}

Teachers ' emotional, physical, mental Burnout made the task of the state, show significant differences according to the type of institution to determine whether the three subdimension, Kruskal-Wallis h test, the general made the task of the state of burnout, ANOVA show significant differences according to the type of institution to determine whether it was applied. The findings are in Table 10 and table 11.

Table 10. Kruskal Wallis Test Results By Institution Type Of Teachers ' Views On Emotional, Mental And Physical Exhaustion

\begin{tabular}{|c|c|c|c|c|c|c|c|}
\hline $\begin{array}{l}\text { Bottom } \\
\text { Size }\end{array}$ & $\begin{array}{l}\text { Studied } \\
\text { Institution }\end{array}$ & $\mathbf{n}$ & Rank Average & Sd & $\chi^{2}$ & $\mathrm{p}$ & $\begin{array}{l}\text { Source Of } \\
\text { Difference }\end{array}$ \\
\hline & Rehabilitation (1) & 31 & 84,42 & \multirow{5}{*}{3} & \multirow{5}{*}{10,021} & \multirow{5}{*}{$\mathbf{0 , 0 1 8 *}$} & \multirow{5}{*}{$1>2$} \\
\hline & Special education class (2) & 17 & 66,68 & & & & \\
\hline & Special education school (3) & 65 & 58,75 & & & & \\
\hline & OÇEM(4) & 23 & 75,93 & & & & \\
\hline & Total & 136 & & & & & \\
\hline & Rehabilitation & 31 & 81,61 & \multirow{5}{*}{3} & \multirow{5}{*}{5,452} & \multirow{5}{*}{0,142} & \\
\hline & Special education class & 17 & 69,29 & & & & \\
\hline & Special education school & 65 & 61,75 & & & & \\
\hline & OÇEM & 23 & 69,33 & & & & \\
\hline & Total & 136 & & & & & \\
\hline & Rehabilitation (1) & 31 & 94,60 & \multirow{5}{*}{3} & \multirow{5}{*}{19,878} & \multirow{5}{*}{$\mathbf{0 , 0 0 0 *}$} & \multirow{5}{*}{$1>2,4$} \\
\hline & Special education class (2) & 17 & 67,65 & & & & \\
\hline & Special education school (3) & 65 & 56,38 & & & & \\
\hline & OÇEM(4) & 23 & 68,20 & & & & \\
\hline & Total & 136 & & & & & \\
\hline
\end{tabular}


Looking at the " $p$ " value in Table 9, teachers ' burnouts differ significantly in the sub-dimension of emotional and physical exhaustion. Looking at the source of the difference in the size of emotional exhaustion, it seems that the burnout of teachers working in rehabilitation centers is greater than the burnout of teachers working in special education classes. Looking at the source of the difference in the size of physical exhaustion, it seems that the burnout of teachers working in rehabilitation centers is higher than the burnout of teachers working in special education classes and the burnout of teachers working in OÇEM.

Table 11. ANOVA results of teachers ' views on general burnout by institution type

\begin{tabular}{|c|c|c|c|c|c|c|c|c|c|c|}
\hline \multirow{2}{*}{$\begin{array}{l}\text { Studied } \\
\text { Institution }\end{array}$} & \multirow[b]{2}{*}{$\mathrm{n}$} & \multirow{2}{*}{$\bar{\chi}$} & \multirow[b]{2}{*}{ SS } & \multicolumn{6}{|c|}{ ANOVA results } & \multirow{2}{*}{$\begin{array}{c}\text { LSD } \\
\text { Source of } \\
\text { Difference }\end{array}$} \\
\hline & & & & $\begin{array}{l}\text { Source of } \\
\text { Variance }\end{array}$ & $\begin{array}{l}\text { Sum of } \\
\text { squares }\end{array}$ & $\mathrm{sd}$ & $\begin{array}{l}\text { Squares } \\
\text { average }\end{array}$ & $\mathrm{F}$ & $\mathrm{p}$ & \\
\hline $\begin{array}{l}\text { Rehabilitation } \\
\text { (1) }\end{array}$ & 31 & 2,85 & ,35 & $\begin{array}{l}\text { Within } \\
\text { group }\end{array}$ & 2,672 & 3 &, 891 & 6,761 & $\mathbf{0 , 0 0 0 *}$ & $1>2$ \\
\hline $\begin{array}{l}\text { Special } \\
\text { education } \\
\text { class }(2)\end{array}$ & 17 & 2,64 & ,49 & $\begin{array}{l}\text { Inter } \\
\text { groups }\end{array}$ & 17,387 & 132 & ,132 & & & \\
\hline $\begin{array}{l}\text { Special } \\
\text { education } \\
\text { school 3) } \\
\end{array}$ & 65 & 2,50 & ,33 & Total & 20,059 & 135 & & & & \\
\hline OÇEM(4 & 23 & 2,66 & ,38 & & & & & & & \\
\hline Total & 136 & 2,63 & ,39 & & & & & & & \\
\hline
\end{tabular}

Looking at the "p" value in Table 11, it seems that the overall burnout levels of teachers differ significantly according to the institution type variable. Looking at the source of the difference, it was found that the general burnout conditions of teachers working in rehabilitation centers were

\section{Burnout Status Of Teachers By Year Of Study In Special Education}

In order to determine whether teachers ' emotional, physical, and mental burnout states differ significantly from the year of study in special education, the Kruskal Wallis $h$ test in three sub-dimensions and Anova were applied to determine whether general burnout states differ significantly from the year of study in special education. The findings are included in Table 12 and table 13.

Looking at the " $p$ " value in Table 12, teachers ' burnouts differ significantly in the subdimension of emotional, mental and physical exhaustion. Looking at the source of the difference in the size of emotional exhaustion, it seems that the burnout of teachers with a working time of 1 year in the field of special education is significantly less than the burnout of teachers with a working time of 5-8 and 9-12 years in the field of special education. higher than the general burnout conditions of teachers working in special education classes. In summary, emotional exhaustion, physical exhaustion and general exhaustion dimensions of teachers working in rehabilitation centers are higher than other teachers.

The difference in size when looking at the source of the mental exhaustion of special education teachers in the field of mental tukenmislik have an operating time of less 9-12 years and more working years was significantly higher than all the other teachers, it was revealed that mental tukenmislik. In addition, the mental burnout of teachers with a working time of 5-8 years in the field of special education is significantly higher than the mental burnout of teachers with a working time of 2-4 years.

Looking at the source of the difference in physical attrition size, teachers with 9-12 years of working time in special education have significantly more physical attrition than teachers with 0-1 years, 2-4 years, 5-8 years of working time. At the same time, teachers with 5-8 years of working time in special education have significantly more physical attrition than teachers with 2-4 years of working time. 
Table 12. Kruskal Wallis Test Results Of Teachers ' Views On Emotional, Mental And Physical Exhaustion By Year Of Study In Special Education

\begin{tabular}{|c|c|c|c|c|c|c|c|}
\hline $\begin{array}{l}\text { Bottom } \\
\text { Size }\end{array}$ & $\begin{array}{c}\text { Year Of Study In Special } \\
\text { Education }\end{array}$ & $\mathbf{n}$ & $\begin{array}{c}\text { Rank } \\
\text { Average }\end{array}$ & Sd & $\chi^{2}$ & $\mathbf{p}$ & Source Of Difference \\
\hline \multirow{6}{*}{ 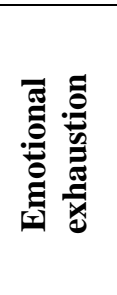 } & $0-1$ year & 38 & 50,78 & \multirow{6}{*}{4} & \multirow{6}{*}{16,433} & \multirow{6}{*}{$\mathbf{0 , 0 0 2} *$} & \multirow{6}{*}{$\begin{array}{l}5-8>0-1 \\
9-12>0-1\end{array}$} \\
\hline & 2-4 year & 43 & 66,21 & & & & \\
\hline & 5-8 year & 31 & 83,66 & & & & \\
\hline & 9-12 year & 16 & 87,56 & & & & \\
\hline & 13 years and over & 9 & 75,78 & & & & \\
\hline & Total & 137 & & & & & \\
\hline \multirow{6}{*}{ 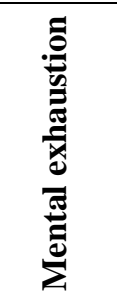 } & 0-1 year & 38 & 62,57 & \multirow{6}{*}{4} & \multirow{6}{*}{24,267} & \multirow{6}{*}{$\mathbf{0 , 0 0 0 *}$} & $9-12>0-1$ \\
\hline & 2-4 year & 43 & 55,10 & & & & $9-12>2-4$ \\
\hline & 5-8 year & 31 & 73,90 & & & & $9-12>5-8$ \\
\hline & 9-12 year & 16 & 110,00 & & & & $9-12>13$ years and \\
\hline & 13 years and over & 9 & 72,78 & & & & $\begin{array}{c}\text { over } \\
5-8>2-4\end{array}$ \\
\hline & Total & 137 & & & & & $5-8>2-4$ \\
\hline \multirow{6}{*}{ 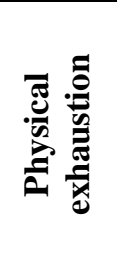 } & $0-1$ year & 38 & 51,99 & \multirow{6}{*}{4} & \multirow{6}{*}{23,363} & \multirow{6}{*}{$\mathbf{0 , 0 0 0 *}$} & \multirow{6}{*}{$\begin{array}{c}5-8>2-4 \\
9-12>0-1 \\
9-12>2-4 \\
9-12>5-8\end{array}$} \\
\hline & 2-4 year & 43 & 63,45 & & & & \\
\hline & 5-8 year & 31 & 75,21 & & & & \\
\hline & 9-12 year & 16 & 106,03 & & & & \\
\hline & 13 years and over & 9 & 80,11 & & & & \\
\hline & Total & 137 & & & & & \\
\hline
\end{tabular}

Table 13. ANOVA results of teachers ' views on general burnout by year of study in the field of Special Education

\begin{tabular}{|c|c|c|c|c|c|c|c|c|c|}
\hline \multirow{2}{*}{$\begin{array}{c}\text { Year Of } \\
\text { Study In } \\
\text { Special } \\
\text { Education }\end{array}$} & \multirow[b]{2}{*}{$\mathbf{n}$} & \multirow{2}{*}{$\bar{\chi}$} & \multirow[b]{2}{*}{ SS } & \multicolumn{5}{|c|}{ ANOVA results } & \multirow{2}{*}{$\begin{array}{c}\text { LSD } \\
\text { Sonuçları } \\
\text { Source Of } \\
\text { Difference }\end{array}$} \\
\hline & & & & $\begin{array}{l}\text { Source of } \\
\text { variance }\end{array}$ & $\begin{array}{l}\text { Sum Of } \\
\text { Squares }\end{array}$ & sd & $\begin{array}{l}\text { Squares } \\
\text { Average }\end{array}$ & $\mathbf{F}$ & \\
\hline $0-1$ year & 38 & 2,45 & ,34 & Withingroup & 4,725 & 4 & 1,181 & \multirow{6}{*}{$10,163 \mathbf{0 , 0 0 0} *$} & $9-12>0-1$ \\
\hline 2-4 year & 43 & 2,55 & ,34 & Inter groups & 15,344 & 132 & ,116 & & $\begin{array}{l}9-12>2-4 \\
0-12>5-8\end{array}$ \\
\hline $5-8$ year & 31 & 2,71 & ,29 & Total & 20,069 & 136 & & & $9-12>13$ years and \\
\hline 9-12 year & 16 & 3,06 & ,40 & & & & & & over \\
\hline $\begin{array}{l}13 \text { years and } \\
\text { over }\end{array}$ & 9 & 2,68 & ,43 & & & & & & \\
\hline Total & 137 & 2,63 & ,38 & & & & & & \\
\hline
\end{tabular}

Looking at the "p" value in Table 13, it seems that the overall burnout levels of teachers differ significantly in the field of special education compared to the variable of the working year. Looking at the source of the difference, it was found that the general burnout conditions of teachers with a working period of 9-12 years in the field of special education were higher than the general burnout conditions of all other teachers with fewer and more working years in the field of special education.
In summary, it turns out that teachers with 912 working years in special education in the subdimensions of emotional exhaustion, mental exhaustion, physical exhaustion, and general exhaustion have significantly higher depletion States than other teachers. In addition, teachers with 5-8 years of work in special education have more burnout than the group with 0-1 years of work in the emotional burnout dimension, and the group with 2-4 years of work in the mental burnout dimension. 
Teachers ' emotional exhaustion states were found to be greater than their mental and physical states. It turned out that the level of burnout was at the level of "sometimes" in the emotional, mental sub-dimensions and general dimension; at the level of "very rare" in the physical dimension. Kaya, Kaya, Aylk and Uygur'un ( 2010) research results showed that the average overall depletion score of nurses was $3.46 \pm 0.68$ and that nurses experienced moderate burnout, nurses experienced the most physical burnout (3.78 \pm 0.85$)$, followed by mental (3.66 \pm 0.54$)$ and emotional $(2.93 \pm 1.03)$ exhaustion. Compared to these two findings, teachers showed less burnout in the physical field than nurses, which can be interpreted as teaching being less strenuous than nursing.

According to the gender variable, male teachers appeared to have higher levels of burnout than female teachers. Emotional, mental, burnout in male teachers more than female teachers in the physical dimensions and overall size of the situation, the challenges male teachers than female teachers in the fight can be interpreted as being superior and more successful. Looking at the source of the difference in the size of emotional exhaustion, it seems that the burnout of teachers with a working time of 1 year in the field of special education is significantly less than the burnout of teachers with a working time of 5-8 and 9-12 years in the field of special education.

Emotional, mental, physical dimensions and overall size there are significant differences between different groups, although in the age group of 18-23 years, the most obvious difference with burnout more than teachers less than the teachers themselves show. In other words, older teachers are more in burnout than younger teachers. It can be interpreted as a natural result that teachers who are advancing age show more burnout than young people due to occupational fatigue. Depending on this finding, as I mentioned in the recommendations, the flexibility of working hours and early retirement rights of older teachers can make them work more efficiently. A study of Kaya, Kaya, Ayık and Uygur (2010) found that nurses aged 25 and six and 26-33 years had a higher level of emotional and physical exhaustion than nurses aged 42 years and older. It was found that there was no significance at the level of mental exhaustion. A study by Yıldıztaşı (2017) found that secondary school teachers ' views on the sub-dimensions of emotional, mental, and physical exhaustion did not show statistical significance compared to the age variable. Dinç (2018) showed that with the increasing age of teachers working in the field of special education, their experience also increases, as a result of this, their subjective wellbeing improves and professional burnout decreases.

It was found that the general burnout conditions of teachers also differed depending on the age variable $(\mathrm{F}=8,265, \mathrm{p}=0,000<0,05)$. Looking at the groups that caused the significance, it was found that the 18-23 age group showed less burnout than teachers who had more age than themselves. In other words, teachers who are older show more burnout than young people. A study of Kaya, Kaya, Ayık and Uygur (2010) found that nurses aged 25 years and under and 26-33 years experienced higher attrition than nurses aged 42 years and older. A study by Kumcağız, Demir, Karadaş (2017) found that there was a negative low-level significant association between the age of school psychological counselors and burnout levels, and it was found that burnout scores decreased as participants ' ages increased. A study by Yıldıztaşı (2017) found that secondary school teachers had similar burnout levels according to their age. Teachers ' depletion states differed significantly only in the physical sub-dimension and overall dimension according to the branch variable.

Teachers differ according to the branch variable, the difference in the state of physical exhaustion of looking at the source when the status of the physical exhaustion of the classroom teacher, special education teacher, Child Development and education teachers and teachers in other disciplines, it was determined that the state of physical exhaustion were high. In addition, it was found that the physical attrition States of preschool teachers are higher than the physical attrition States of Child Development and learning teachers. Looking at the differentiation state of the general burnout States of teachers according to the branch variable, it was found that the general burnout States of classroom teachers are higher than the general burnout States of Child Development and education teachers. As a result, teachers who are classroom teachers and work in 
the field of special education have been in a lot of burnout compared to other teachers, both physically and in general burnout. Classroom teachers ' work in a field that is more difficult than their field in terms of work difficulties may have caused their burnout to be high.

According to the type of institution in which teachers work, their burnout significantly differs from the sub-dimensions of emotional and physical exhaustion and the overall burnout size. Teachers working in rehabilitation centers in all three areas have more burnout than teachers working in special education classes and teachers working in the lower dimension of physical exhaustion, as well as in OÇEM. Because the working conditions in rehabilitation centers were more severe than in other areas, teachers working here showed more burnout than teachers working in other areas of special education. Teachers ' burnouts differed significantly in the subdimensions of emotional burnout, mental burnout, physical burnout, and overall burnout size according to the study year variable in the field of special education. In particular, teachers with a working time of 9-12 years show more burnout in the field of special education than teachers with less working time than themselves.

In other words, teachers with 9-12 years of working time in the field of special education are in more burnout than teachers with fewer years of working in the field of special education than they are. In other words, teachers with a lot of working Years exhibit more burnout than teachers who are younger than them. Because the resistance of these teachers to difficult working conditions decreases as the year progresses. A study of Kaya, Kaya, Aylk and Uygur (2010) found that nurses working in the same institution for 3 years and six to 4-7 years had a higher level of emotional and physical exhaustion than nurses working in the same institution for 12 years and above. It was found that there was no significance at the level of mental exhaustion. A study by Yıldıztaşı (2017) found that the views of secondary school teachers on the sub-dimensions of emotional, mental and physical exhaustion were not statistically significant compared to the study year variable in the institution. Gönüldaş (2017) found that teachers orking in special education for more than 10 years had higher burnout levels. The researcher also concluded that the teachers with the lowest level of burnout were teachers who worked in special education for 7-9 years.

Looking at whether the general burnout conditions of teachers differ according to the working year variable in special education, it was found that the general burnout conditions of teachers working for 9-12 years in special education were higher than the general burnout conditions of teachers working for $0-1,2-4,5-8$ years and 13 years and above. Teachers who have more than a year of work in the field of Special Education show more burnout than young people, which can be interpreted as a decrease in their resistance to difficult working conditions. The fact that teachers with more working years show more burnout than teachers with more working years can also be interpreted as desensitizing teachers with more working years, being in learned helplessness. A study of Kaya, Kaya, Ayık and Uygur (2010) found that nurses working in the same institution for 3 years and six to 4-7 years had higher burnout than nurses working in the same institution for 12 years and above. A study by Yildıztaşı (2017) found that the views of secondary school teachers on burnout were not statistically significant compared to the variable of the year of study in the institution.

\section{CONCLUSION}

Special education is an area of education aimed at educating children whose development is not at a normal level and living smoothly in society. The special educational needs of children who develop more slowly than their peers arise based on genetic, social, psychological and educational factors. The increasing trend of the need for special education has also led to an increase in research on teachers working in this field. Burnout, which occurs as a negative result in stressful and difficult business life, is a significant threat due to the impact of various difficulties encountered in the field of special education.

In this study, which involved 142 teachers working in special education in Eyüpsultan District of Istanbul province, the burnout levels of teachers working in special education and the difference of burnout according to age, gender, branch, type of institution studied, year of work in special education were investigated. The results obtained in the study can be stated as follows:

It reveals that teachers sometimes tend to burn out. This conclusion has been reached as a result 
of separate investigations in terms of physical exhaustion, mental exhaustion and emotional exhaustion.

1) Emotional exhaustion States of teachers were found to be greater than their mental and physical states. It turned out that the level of burnout was at the level of "sometimes" in the emotional, mental sub-dimensions and general dimension; at the level of "very rare" in the physical dimension.

2) According to research results conducted in terms of gender and teacher burnout, male teachers have a higher level of burnout than female teachers.

3) According to the results of the research on the relationship between burnout and age of teachers working in the field of special education, it was determined that the burnout levels of teachers in the 18-23 age range were the lowest. A higher level of burnout in other age groups than in this age group indicates that the likelihood of burnout increasing is higher as age increases.

4) In the research conducted on the branch variable, no differences were observed in the states of emotional exhaustion and mental exhaustion of teachers, and differences were observed in accordance with the state of physical exhaustion. According to the results obtained, it was found that the physical attrition conditions of classroom teachers working in the field of special education are higher than the physical attrition conditions of special education teachers working in special education, child development and education teachers and teachers from other branches. In addition, it was found that the physical attrition States of preschool teachers are higher than the physical attrition States of Child Development and learning teachers. In addition, it was found that the general burnout status of classroom teachers is higher than the general burnout status of Child Development and education teachers.

5) According to the examinations conducted to determine whether the working conditions of teachers in institutions such as special education class, special education school, rehabilitation, autistic children education center affect burnout, the type of institution studied affects the level of burnout. Such a result occurs because different types of institutions require different special educational skills and each has its own unique challenges.

6) Similarly, the year teachers work in the field of Special Education reveals significant effects on burnout. Accordingly, teachers who work in the field of special education for 5-8 years have higher emotional exhaustion than teachers who work for 0-1 years. It shows that teachers working for 9-12 years in the field of special education have a higher state of emotional exhaustion, mental exhaustion, physical exhaustion and general burnout than teachers working for $0-1,2-4,5-8$ years. Similar to the age variable, with increasing study time, teachers ' burnout levels also increase. The fact that the burnout levels of teachers serving in the 0-1 year range are lower than those of other teachers suggests that the two results support each other.

\section{According to the results of the research, the following are recommended:}

1. In our research findings, burnout appeared to increase as age progressed and occupation seniority increased. As for this finding, teachers working in the field of special education should be shown flexibility due to the share of attrition factor; improve working hours as part of flexibility, offer opportunities such as summer holidays and semester holidays, and. it is recommended that the opportunity for early retirement be offered will be important.

2. It has been revealed that male teachers show significantly more burnout than female teachers. Accordingly, men who choose to work and become teachers in the field of special education are recommended to consider aspects such as patience, tolerance towards the disabled, and empathy.

3. A study of the branch found that teachers with primary school teacher backgrounds had more burnout. According to this finding, it is recommended that teachers of primary education origin be careful in their appointment in the field of special education; those who are not patient and do not have empathy and tolerance towards the disabled should not be appointed.

4. Another finding in the study was that teachers working in a rehabilitation center had higher burnout levels. Accordingly, it is appropriate for teachers working in rehabilitation centers to show work flexibility, reduce working hours, increase vacation and rest periods, and recognize early retirement.

5. It is recommended to conduct research aimed at uncovering the burnout levels and causes of teachers working in other fields. 
6. In order to contribute to the determination of the causes of burnout, it is recommended that teachers working in the field of special education conduct interviews with the families of children.

\section{REFERENCES}

Akalin, S. (2015). Opinions and requirements of teachers of the fusion class on Classroom Management, Journal of the Faculty of Education of Ankara University, 16 (3), 215-234.

Ardıç, K. and Polatçı, S. (2008). Burnout syndrome: an application on academics, Journal of the Faculty of Economics and Administrative Sciences, 10 (2), 69-96.

Ardıç, K. and Polatçı, S. (2009). Burnout syndrome and the other side of the coin: integration with work. Erciyes University Journal of the Faculty of Economics and Administrative Sciences, 32, 2146.

Budak, G. and Sürgevil, O. (2005). An application on academic staff related to the analysis of organizational factors affecting burnout and burnout, Dokuz September University Journal of the Faculty of Economics and Administrative Sciences, 20 (2), 95-108.

Bayrakdar, Uygar., Vural Batık, M. and Barut, Y. (2016). Special education teachers and candidates ' self-determination levels and attitudes towards the teaching profession, Journal of the Faculty of Education of Ahi Evran University, 17( 2), 133-149

Çapri, B. (2006). Turkish adaptation of burnout scale: validity and reliability study. Journal Of Mersin University Faculty Of Education, 2 (1), 62-77.

Dinç, G. (2018). Examination of vocational burnout levels and subjective well-being levels of special education teachers working in special education institutions. Master's Thesis, Biruni University Institute Of Educational Sciences, Istanbul.

Gündüz, M. and Akin, A. (2015). Problems and solutions related to special education in public schools in Turkey, Journal of Education and Training Research, 4 (2), 86-95.

Gönüldaş, H. (2017). Examination of self-sufficiency perceptions and anxiety and burnout levels of special education teacher candidates and teachers. Master's Thesis, Anadolu University Institute of Educational Sciences, Eskişehir.
Karasu, T. and Mutlu, Y. (2014). Problems and solutions in special education from the perspective of teachers, Journal of Social Sciences of mush Alparslan University, 2 (1), 4766.

Kaya, N., Kaya, H., Erdoğan Ayık, S. and Uygur, E. (2010). Burnout in nurses working in a public hospital. International Journal of Human Sciences, 7 (1), 401-419.

Kumcağız, H., Demir, Y. and Karadaş, C. (2017). Selfsufficiency perception of special education as predictor of professional burnout in school psychological counselors. Journal of The Faculty of Education of Inonu University, 18 (3), 315324.

Maslach, C. and Goldberg, J. (1998). Prevention of burnout: new perspectives. Applied \& Preventive Psychology, 7, 63-74.

Ministry of family and social policies of the Republic of Turkey, http://eyh.aile.gov.tr/data/549c100e369dc526905 eb409/zihinsel\%20engelli\%20\%C3\%A7ocuklar. pdf Accessed 13.02.2018.

Sağlam Arı, G. and Çına Bal, E. (2008). Burnout concept: its importance for individuals and organizations, Journal of Management and Economics, 15 (1), 131-148.

Şahin, F. and Şahin, D. (2012). Determination of burnout level of special education teachers working with disabled individuals, Journal of Teacher Education And Educators, 1 (2), 275294.

Tümeğ, S. (2014). The effectiveness of simultaneous teaching offered by a peer with mental disabilities in learning the coins of students with mental disabilities. Master's Thesis, Abant Izzet Baysal University Institute of Educational Sciences, Bolu.

Yıldıztaşı, M.B. (2017) .An examination of the relationship between political skill and organizational burnout in accordance with the views of secondary school teachers. Master's Thesis, Hacettepe University Institute of Educational Sciences, Ankara

How to cite this article: Kaya, B. and Köklü, M. (2021). Burnout Levels of Teachers Working In Special Education. Int J Disabil Sports Health Sci;4(1):8-23. $\quad$ https://doi.org/10.33438/ijdshs. 825950 